\section{SEVENTEENTH-CENTURY VISITORS TO INDIA}

Indian Travels of Thevenot and Careri

Being the Third Part of the Travels of M. de Thevenot into the Levant and the Third Part of a Voyage round the World by Dr. John Francis Gemelli Careri. Edited by Surendranath Sen. (Indian Records Series.) Pp. lxiv $+434+20$ plates. (New Delhi : National Archives of India, 1949.) 20 rupees.

T HIS volume forms one of the Indian Records Series; it differs, however, from its predecessors in that it is not strictly a 'record' of India but is the impression of two foreign visitors. Many travellers, merchants and diplomats visited India in the seventeenth century, and the editor has selected two of their accounts for publication in this Series. Jean de Thevenot was in the country during 1666-67, as a young man aged thirty-three; Giovanni Francesco Gemelli Careri reached India in 1695, when he was forty-four. Their accounts were translated into English in 1687 and 1704, respectively, and these translations are now reprinted and edited by Dr. Surendranath Sen, director of the National Archives of India.

It can be said at once that this edition owes almost everything to Dr. Sen. He has contributed a most interesting and valuable introduction which draws on all the foreigners who visited the country during the century, and makes useful comparisons between their records. Dr. Sen has also added a vast appendix of notes, itincraries, bibliography and index, and it is probably true to say that little more could be added to what he has written. On these grounds Dr. Sen deserves both congratulations and thanks.

Explaining the general ignorance of the geography of India in the seventeenth century, Dr. Sen remarks of the travellers generally: "they did not know the country as a whole and in most cases their stay was all too brief". This is a fair comment on both Thevenot and Careri. The first arrived at Surat in January 1666 and returned there in the following December. In a little more than eleven months, he travelled over a strip of country across the peninsula from Ahmedabad "built in a lovely plain" to the "excellent" coast of Coromandel, whence came ships of all nations. Thevenot himself saw there "Cochin Chinese, Men of Siam, Pegu, and of many other Kingdoms of the east". This was a very small part of India, and yet Thevenot writes about many other districts as if he knew them, and in consequence falls into error. Similarly, Careri reached Daman in January 1695 and sailed from Goa in the following May. Except for one short journey inland from Goa to Galgali, on the Kistna river, "where the Moguls' camp was", his route was down the west coast. This one encounter with the army of Aurangzeb gives him a chance to write of the Mogul Empire, and elsewhere he deals briefly with such matters as "the climate, fruit, flowiers, minerals, beasts, and coin" of Indostan.

The errors of these travellers, which are corrected by Dr. Sen's notes, do not make their accounts worthlesis, and there is a wealth of material here of the greatest value-descriptions of ports, customs of the people, methods of travel, roads and natural resources, to name only a few. It is impossible to do justice to all this material in a short review. Further, where these travellers overlap they can be checked with each other. Thevenot gives almost correctly the latitude of Surat-Careri is a degree out ; the "almost all ruinous" walls in 1666 were still "weak" thirty years later; and so on.

There are a great many printer's errors in this book, and a Government which has such a splendid service as the Survey of India might have produced two better maps to illustrate the scholarly work of its director of archives. J. N. L. BAKER

\section{MODERN DEVELOPMENTS IN PROTEIN CHEMISTRY}

Advances in Protein Chemistry

Edited by M. L. Anson and John T. Edsall. Vol. 5. Pp. ix +481 . (New York: Academic Press, Inc., 1949.) 7.50 dollars.

7 HIS volume opens with a fine review by J.S. Fruton, who surveys in a masterly manner the development of synthetic methods and presents tables of every peptide that has been prepared. Our knowledge of the enzymic synthesis, hydrolysis and transfer of peptide bonds is now entering an exciting stage, and it is indeed fortunate to be ablo to refer to such a review for the preparation of the peptides, upon which so much of this work hinges.

G. R. Tristram in his review on the amino-acid composition of purified proteins gives an able discussion of the existing methods of analysis, the useful interpretations that can be made from analytical results and the rules to be observed, not only for interpretations but also in the methods for presenting data. It is clear that, for most of the amino-acids, methods have reached a fairly reasonable standard of accuracy.

In the reviewer's opinion, too many nutritionists use a teleological method of expression. J. B. Allison is one of these; to quote an example (p. 169): "The breakdown of tissue to supply the methionine on a protein-free diet could be reflected by a high excretion of urinary body nitrogen". This sentence ignores the dynamic approach that would explain the nitrogen excretion on the basis of a drain on methionine produced by protein turnover and which would rcsult in the accumulation of amino-acids due to the failure to resynthesize protein because of a mothionine shortage. Allison's review does, however, contain a good discussion of the methods and problems of the biological evaluation of proteins.

T. L. McMeekin and B. D. Polis have made a useful collection of the published data on milk proteins. Plant proteins are reviewed by J. W. H. Lugg, chiefly from the point of view of the analyst. From a collection of what he believes to be the most reliable data, Lugg has made several phylogenetic generalizations based on the amount and variety of amino-acids found in the bulk proteins of different plant types. It must be remembered, however, that for the Pteridophytes, Bryophytes and Algæ they are based on the analyses of very few amino-acids. A more interesting speculation made in this article is that protein denaturation leads to the degradation and resynthesis of protein or, in other words, the protein cycle, and that this would account for a proportion of the respiration of the resting cell because this resynthesis can only be achieved by energy-requiring mechanisms.

H. P. Lundgren's review of synthetic fibres made from proteins is excellent. With his clear oxpression and simplo models, everything has been made easy for the reader. 